\section{JUNIOR COLLEGE LIBRARIES INFORMATION CENTER}

\author{
By Peggy Sullivan
}

When the Junior College Libraries Section of the Association of College and Research Libraries received $\$ 15,000$ as a J. Morris Jones-

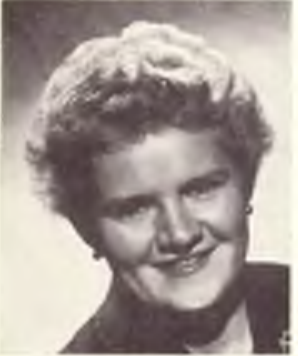

Miss Sullivan World Book Encyclopedia-ALA Goals Award at the San Francisco conference in 1967 , it was an appropriate and well deserved recognition for one of ALA's liveliest sections. The money was to be used to support a Junior College Library Information Center at ALA headquarters for a period of one year. Sharply reduced from the amount which the section had originally requested, this fund provided salaries of a half-time project director and a half-time secretary, a modest budget for materials, and the related expenses of correspondence, advisory assistance from a blue-ribbon advisory committee, and similar expenses associated with a project of this kind. There was a short-lived hope that some other source of funds might bring the sum up to the $\$ 24,000$ originally requested, but that was not to be.

The title of the Center was carefully selected so that it would logically include private twoyear colleges as well as community colleges. Sometimes, in press releases or in news items about the Center, there has seemed to be confusion. The Center's concern is libraries in two-year colleges.

One of the difficulties of a short-term Project with funds only for a half-time staff is, as would be expected, the recruitment of personnel. By setting March 1, 1968, as the opening date for the Project, it was possible to recruit two staff members formerly associated with the Knapp School Libraries Project, which terminated February 29. Janet Winandy serves as secretary while completing her senior year of college, and Peggy Sullivan serves as director while working toward a doctoral degree at the graduate library school of the University of Chicago. The termination date for the Junior College Project is February 28, 1969.

A three-man advisory committee was appointed by ACRL and the American Association of Junior Colleges. Members are Richard L. Ducote of College of DuPage, chairman; Norman E. Tanis of Kansas State College in Pittsburg; and Clifford G. Erickson of Rock Valley Community College. Since they are, respec- tively, a junior college librarian, college librarian with extensive junior college experience, and junior college president, they bring individual interests and abilities to the service of the Center. The first meeting of this committee was held at American Library Association Headquarters Friday, May 10, 1968. At that time, the committee examined materials gathered to date, set priorities for future acquisitions, and recommended policies for general operation of the Center.

As outlined in the proposal for the Project, these are the purposes it serves and the kinds of materials it is intended to collect:

1. Produce, for publication, lists of documents, studies, and plans, indexed by subject, type, and size of junior college.

2. Make the resulting collection available to junior college personnel through interlibrary loan. (This service was later revised to note that the Center would not provide materials on interlibrary loan, but would work only through Headquarters Library).

3. Prepare brief summaries of activities of the Center for publication in CRL News, the Junior College Journal, other library and educational publications.

4. Materials to be collected:

a. Booklists and guides to book selection

b. Orientation programs-descriptions, manuals, etc.

c. Programs of special services to faculty, students, and the community-descriptions, manuals, etc.

d. Budgets

e. Surveys-by library consultants, selfsurveys, commercial surveys

f. Annual reports - to provide information about programs, plans, and needs, as a means of securing information for future statistical evaluation

g. Bibliographies compiled by junior college librarians-to provide information for planning of all phases of junior college library development

h. Buildings-programs plans and statements, in cooperation with the Library Administration Division

i. Federal funds-information about available funds, possible uses of such funds, past utilization of funds, and needs

j. Cooperative programs-information about present activities in such areas as purchasing, processing, and sharing of services

k. Standards-collection of existing statements on state, regional and national basis; and statements about utilization of standards by various groups of librarians, administrators, educational organizations, and accrediting associations

1. Innovative programs-statements for the improvement of library service 


\section{LIBRARY OF CONGRESS CATALOG}

\section{on microfiche}

\section{$\$ 699.00$}

"Because of the immensity of the collections, the excellence of the cataloging, and the full bibliographic descriptions, the Catalog of the Library of Congress has been for many years an invaluable work in any library and indispensable in those where research is done. Of first importance in cataloging, acquisition, and reference work, and for the bibliographer and research worker, it is valuable for author bibliography, verification of titles, bibliographical information, historical notes, location of copies, etc."

"Scope: It is an author and main entry catalog (with cross references but not added entries) of books and other materials for which Library of Congress Printed cards were available in: (1) the Library of Congress (as cards had not been printed for all the Library's books, the catalog is not a complete record of the Library's holdings, but does represent a large percentage); (2) many government department libraries; (3) various libraries throughout the country as a result of the cooperative cataloging program."

"Information given is detailed and represents a high degree of accuracy usually including, as pertinent: full name of author, dates of birth and death; full title; place, publisher, and date; collation; series; edition; notes on contents, history, etc.; tracing for subject headings and added entries; L.C. class number, sometimes Dewey class number, and L.C. card number," Winchell, Guide To Reference Books (8th edition), entry AA63.

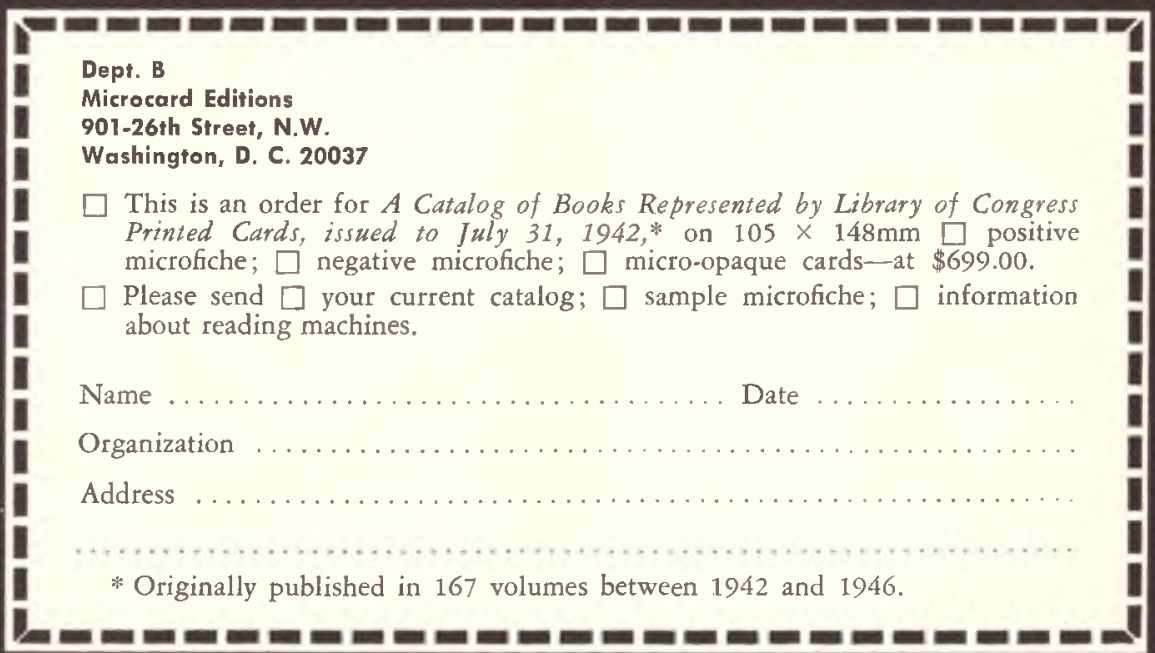

\section{NTCR MICROCARD EDITIONS}


m. Automation-existing program statements in junior college libraries

It is easy to see from this statement that there are many possible lines of intercommunication and, indeed, confusion with other offices at ALA and with related agencies outside. An obvious relationship exists with the Educational Resources Information Centers (ERIC clearinghouses) at University of California, Los Angeles, for junior colleges, and at University of Minnesota for libraries. As a much smaller operation, with an annual budget approximating a monthly budget at either of these clearinghouses, the ALA Junior College Library Information Center must have a narrower focus but one which combines both of those ERIC centers' concerns. Somewhat unexpectedly, the center at ALA has also attracted a sizeable number of general reference questions from librarians and others both within and outside the junior college field. These have included:

Where may we sell a junior college library collection from a college now being discontinued?

What are typical expenditures for periodicals in a junior college library of our size?

How may I get in touch with junior college library personnel in my own or neighboring states?

Again, this kind of question illustrates many possible overlaps with ALA offices. Questions of budget, administration, and recommendations of consultants are within the purview of the Library Administration Division; materials to be borrowed from ALA headquarters are logically the responsibility of the headquarters library, which has a well established procedure for treatment of interlibrary loans; many questions relating to library technical assistant programs in junior colleges are the natural concern of both the Office of Library Education and the Library Education Division. These facts have prompted a meeting with staff members from these headquarters offices and some fairly firm agreements about responsibilities.

Because of the growth of activities and membership in the Junior College Libraries Section and because so many of the institutions represented by those members are in growing and changing stages themselves, there are, predictably, many questions of general interest and concern which seem to be directed to the Center. These include inquiries about membership, publications and materials that have been published or are forthcoming about junior college libraries (three major bibliographies slated for 1968 publication, for example!). Frustrating as it is to be building a collection with set priorities and goals which do not always match the requests received from the field, we have attempted to the extent possible to service such requests. We will continue to do so.
A logical questions is: What happens to materials collected by the Center after the Center itself goes out of existence? To avoid inundating the headquarters library with materials in late February, 1969, our plan is to forward relevant materials to that collection as they are received. The perennial problems of limited staff, budget, and time place a ceiling on how much even of free materials the library is able to request and to absorb into its collection, but our gradual approach and continued communication are planned to assist rather than to burden that staff and those facilities.

An example of one area in which junior colleges are represented only minimally in the headquarters library collection is in the slides of library buildings. The current eight-page listing of slides includes new library facilities for the most part. Of the eighty-six institutions listed, only four are junior colleges, and in the collection totaling 1,192 slides seventeen slides are of junior colleges. Considering the many junior colleges now in building programs or contemplating them, this meager representation appears to offer little assistance. Yet the task of requesting slides, follow-up on articles about new buildings, etc., is a time-consuming one which has not called on any ALA staff member's primary interest.

We have rather carefully examined such collections as the student handbooks on file in headquarters library and frequently requested on loan. This collection for the most part dates from 1964, when a Junior College Libraries Section committee chaired by Mrs. Alice Griffith sent out many requests and built up a collection which has been arranged so that a librarian requesting materials will receive a selection of handbooks in varied formats and from colleges in varied locations, with different purposes for use of the handbooks. In updating this collection, we have also benefited greatly from the generosity of junior college libraries which have provided annual reports, self-surveys, bibliographies, information about buildings, and other materials.

At the present time and probably throughout the Project, it is our plan to make up lists of materials and to identify sources where copies might be obtained while also permitting, within the limits of staff time and space, visitors to use materials in the Center. This will undoubtedly mean that more calls will be made on the junior colleges which have materials that others can use as models or which have provided most materials to the Center, but it also should mean that the kinds of requests made will be more precise and may be answered by materials available.

College and Research Libraries News is the Center's link with the membership of the Junior College Libraries Section and, beyond that, with the Association of College and Re- 
search Libraries. This brief report is expected to be only the first of several on this one-year Project.

One of four recipients of the 1968 Tangley Oaks graduate fellowship grants is Peggy Sullivan, who recently concluded her appointment as director of the American Library Association's five-year Knapp School Libraries Project and now heads the Junior College Library Information Center for ALA. Miss Sullivan was granted $\$ 2500$ for work toward her doctoral degree in the graduate library school at the University of Chicago. Award recipients were chosen by the United Educators Foundation selection committee for the eighth year of the Tangley Oaks Graduate Fellowship program. With this year's awards, a total of twenty-five graduate fellowships have been granted since the inception of the program in 1960.

Miss Sullivan was graduated maxima cum laude from Clarke College, Dubuque, Ia., in 1950 , a major in language and literature, and received her master's degree in library science from Catholic University, Washington, D.C., in 1953.

\section{COLLEGE LIBRARY NOTES}

A NEW COMMUNiCATION MEDrum designed to inform college presidents of current library developments will be published by ACRL and the Association of American Colleges, with the aid of a grant from the Shell Companies Foundation. College Library Notes will be published four times a year under the direction of the Joint Committee on College Library Problems of the two associations. Basil Mitchell, executive director of the Southeastern New York Library Resources Council, will edit the publication, now scheduled for initial distribution in September. Editorial address of publication is 103 Market St., Poughkeepsie, N.Y. 12601.

\section{From Inside the DLSEF}

By Dr. Katharine M. Stokes

College and University Library Specialist, Library Planning and Development Branch, Division of Library Services and Educational Facilities, U.S. Office of Education, Washington, D.C. 20202.

You have probably read in your state library or state association publications the announcements of awards to library education programs. These awards will enable library educators to conduct institutes for intensive training to upgrade and update the competencies of persons serving all types of libraries. These institutes are funded under authority of Title II-B of the Higher Education Act and vary in length from two weeks to a semester or more. At least fifteen of them are related to some phase of academic librarianship.

The University of California offers two-week programs in map librarianship or oral history at its Los Angeles campus, and a month-long institute in law librarianship at Berkeley. Institute participants at the University of Maryland, College Park, will study the automation of bibliographical services. The University of Hawaii, Honolulu, offers a six-week institute on Asian materials for college libraries. At the University of Michigan, Ann Arbor, one may study junior and community college librarianship for six weeks. Participants in the University of Oregon's program at Eugene will work part-time from summer to midwinter on mechanization in technical services and circulation areas of the library. In April, the University of Washington, Seattle, will offer a twoweek program on library executive development, and in June 1969, the University of Wisconsin, Madison, will offer a two-week study of bibliographic services in East Asian studies. These are examples of the sixty-three institutes being offered; a complete listing may be obained from the DLSEF.

There is a $\$ 75$ a week stipend plus $\$ 15$ for each dependent during the institute period; no travel money is included. It is suggested that you begin planning quickly, as some of these institutes start in the middle of June. If you cannot attend an institute, perhaps you have a friend who should be encouraged to go. Any person who has been or is engaged in librarianship, or who has an undergraduate or graduate degree in library science may apply. Information, admission requirements, and application forms for institutes should be obtained from the school offering the program. 